\title{
Daya Simpan Konsentrat Sapi Potong Dengan Jenis Kemasan Berbeda Terhadap Kualitas Nutrisi, Ketengikan, dan Kandungan Aflatoksin
}

\section{Stability of Beef Cattle Concentrate with Different Types of Packaging on Nutrition, Rancidity, and Aflatoxin Content}

\author{
Halimatuddini ${ }^{1 *}$, Y. Marlida ${ }^{2}$, M. Zain ${ }^{2}$, dan Elihasridas ${ }^{2}$ \\ ${ }^{1}$ Program Pascasarjana, Fakultas Peternakan, Universitas Andalas, Padang \\ ${ }^{2}$ Program Studi Peternakan, Fakultas Peternakan, Universitas Andalas, Padang \\ *E-mail: halimatuddini55@gmail.com
}

(Diterima: 22 Juli 2019; Disetujui: 19 September 2019)

\begin{abstract}
ABSTRAK
Tujuan penelitian adalah untuk memperoleh jenis kemasan dan waktu penyimpanan pakan konsentrat sapi potong yang terbaik berdasarkan kualitas nutrisi, ketengikan dan kandungan aflatoksin. Penelitian ini menggunakan rancangan acak lengkap (RAL) pola faktorial $2 \times 3 \times 3$ dengan dua faktor. Faktor A yaitu Jenis Kemasan (A1 = woven bag; A2 = woven bag dilapisi plastik PE (polyethylene)) dan Faktor B yaitu Waktu Penyimpanan (B1 = 1 bulan; B2 = 2 bulan, B3 = 3 bulan) dengan ulangan 3 kali. Peubah yang diamati adalah kualitas nutrisi (bahan kering, lemak kasar, protein kasar), ketengikan, dan kandungan aflatoksin. Hasil penelitian menunjukkan adanya interaksi antara faktor A (jenis kemasan) dan faktor B (lama penyimpanan) terhadap penurunan bahan kering, protein kasar, lemak kasar namun terjadi peningkatan tingkat ketengikan dan kandungan aflatoksin. Jenis kemasan woven bag yang dilapisi plastik menunjukkan kandungan nutrisi yang lebih baik dibandingkan kemasan woven bag berdasarkan kandungan nutrisi, ketengikan, dan kandungan aflatoksin selama penyimpanan 2 bulan.
\end{abstract}

Kata kunci: aflatoksin, daya simpan, ketengikan, pakan ternak

\section{ABSTRACT}

The purpose of this research was to obtain the best type of packaging and storage time of beef cattle concentrate based on the quality of nutrition, rancidity, and aflatoxin content. This research used a completely randomized design (CRD) $2 \times 3 \times 3$ factorial pattern with two factors: factor A is type of packaging A1: woven bag; A2: woven bag plastic PE (polyethylene) and factorial B is storage time (B1: 1 month; B2: 2 months, and B3: 3 months). This research was repeated 3 times. The variables observed were the quality of nutrition (dry matter, crude fat, crude protein), rancidity, and aflatoxin content. The results showed that there was an interaction between factor A (type of packaging) and factor B (storage time) to decrease in dry matter, crude protein, crude fat, however, there was an increase of rancidity and aflatoxin content. The type of woven bag packaging that is coated with plastic showed that the nutrient content is better than just woven bags based on the nutritional content, rancidity and aflatoxin content during 2 months storage.

Keywords: aflatoxin, cattle feed, rancidity, storage ability

\section{PENDAHULUAN}

Ternak potong merupakan sumber protein hewani untuk manusia agar terjamin ketersediaan akan protein hewani maka perlunya peningkatkan produktivitas ternak potong. Menurut Utomo (2003) pertumbuhan peternakan di Indonesia masih dihadapkan pada beberapa masalah, yaitu ketersetiadaan pakan secara kontiniu dan nilai nutrisi yang rendah.

Pakan adalah kebutuhan utama dari segi usaha peternakan. kebutuhan akan pakan tentunya tidak terlepas dari aspek pakan yang 
berkualitas dan dapat tersedia secara kontinu. yang diberikan dengan kandungan nutrisinya memenuhi kebutuhan hidup pokok dan kebutuhan produksi. Ketersedian hijauan dan pakan lainnya secara kontiniu sangat fluktuatif dipengaruhi kondisi iklim Indonesia oleh karena itu perlunya melakukan penyimpanan pakan atau bahan pakan, agar terpenuhinya kebutuhan pakan. Penyimpanan merupakan salah satu bentuk tindakan penyediaan pakan secara terus menerus yang bertujuan untuk mempertahankan komoditi yang disimpan dalam jangka waktu tertentu dengan menghambat faktor penyebab terjadinya penurunan kualitas dan kuantitas pakan.

Konsentrat tersusun dari biji-bijian yang umumnya memiliki nilai nutrisi lebih baik dibandingkan dengan rumput. Kandungan nutrisi yang tinggi menyebabkan konsentrat mudah sekali mengalami penyusutan. Penyusutan ini dapat berupa penyusutan kuantitatif dan penyusutan kualitatif. Penyusutan ini erat kaitannya degan lama waktu penyimpanan.

Kandungan air bahan dapat mempengaruhi daya simpan tiap jenis bahan, dimana antara daya simpan dengan kadar air berbanding terbalik, sehingga menyebabkan kadar air yang meningkat selama penyimpanan dapat menimbulkan kerusakan zat nutrisi pakan sesuai dengan pendapat Buckle et al. (2013) mengemukakan bahwa dalam proses penyimpanan terjadi perubahan-perubahan bahan makanan yang akan menurunkan kualitas nutrisi pakan yang disimpan.

Lemak mengalami interaksi antara sejumlah oksigen maka akan terjadi proses oksidasi. Lemak mengalami interaksi antara sejumlah oksigen maka akan terjadi proses oksidasi sehingga menimbulkan bau tengik oleh radikan bebas. Radikal bebas adalah molekul ketengikan sebagai indikator dari kerusakan lemak dan minyak, ketengikan dihasilkan oleh autooksidasi asam lemak tak jenuh yang menimbulkan bau dan flavor yang tidak menyenangkan dan membuat pakan tidak enak (Zuhra, 2006).
Penyimpanan pakan dapat mengalami kerusakan akibat adanya aktifitas mikroba seperti tumbuhnya jamur. Aflatoksin adalah jenis toksin yang bersifat karsinogenik dan dapat mengakibatkan keracunan dengan gejala mual dan muntah, serta bila berlangsung lama penyakit yang timbul adalah kanker hati yang mengakibatkan meninggal dunia. Apabila seseorang mengkonsumsi bahan pangan yang terkontaminasi aflatoksin konsentrasi rendah secara terus-menerus, maka hal itu dapat merusak hati serta menurunkan sistem kekebalan pada tubuh. Hal ini tentunya akan mempengaruhi kualitas konsentrat yang semakin menurun, untuk melindungi konsentrat dari kerusakan oleh faktor lingkungan dapat dilakukan upaya pengemasan, sehingga dapat melindungi konsentrat dan mengawetkan produk.

Pengemasan dilakukan agar mempertahankan nutrisi konsentrat selama penyimpanan. Bahan yang umum digunakan untuk mengemas pakan buatan adalah karung plastik anyaman untuk bagian luar, sedangkan untuk bagian dalam dilapisi kantong plastik tipis, transparan. Bagian kantong plastik itulah yang membuat pelet/pakan buatan terisolasi dari udara bebas, sedangkan karung plastik anyaman merupakan pelindung agar kantong plastik tidak mudah bocor serta memudahkan dalam pengangkutan yang dinyatakan oleh Retnani (2015).

Penelitian ini bertujuan mengetahui daya simpan konsentrat sapi potong terhadap kualitas nutrisi konsentrat sapi potong dengan jenis kemasan yang berbeda selama penyimpanan 1, 2, dan 3 bulan.

Penelitian ini diharapkan dapat memberikan informasi kepada peneliti, peternak dan pembaca tentang daya simpan konsentrat (bungkil inti sawit, dedak padi, ubi kayu dan mineral) sapi potong dengan jenis kemasan yang berbeda terhadap kualitas nutrisi, ketengikan dan kandungan aflatoksin. 
Tabel 1. Rataan penurunan kandungan bahan kering konsentrat (\%)

\begin{tabular}{lcccc}
\hline \multirow{2}{*}{ Jenis Kemasan } & \multicolumn{3}{c}{ Waktu Penyimpanan } & \multirow{2}{*}{ Rataan } \\
\cline { 2 - 4 } A1 & $\mathrm{B} 1$ & $\mathrm{~B} 2$ & $\mathrm{~B} 3$ & $2,18^{\mathrm{aA}}$ \\
A2 & $2,03^{\mathrm{cA}}$ & $2,67^{\mathrm{bA}}$ & 2,96 \\
\hline Rataan & $0,53^{\mathrm{cB}}$ & $1,87^{\mathrm{bB}}$ & $2,72^{\mathrm{aB}}$ & 1,71 \\
\hline
\end{tabular}

Keterangan: nilai-nilai dengan superskrip huruf lebih kecil berbeda pada baris sama serta nilai dengan superskrip huruf besar yang berbeda pada kolom yang sama menunjukkan perbedaan yang nyata $(\mathrm{P}<0,05)$

\section{METODE}

\section{Tempat dan Waktu Penelitian}

Penelitian ini dilakukan di Laboratorium Nutrisi Ruminansia Fakultas Peternakan Universitas Andalas. Penyimpanan Konsentrat selama 3 bulan dengan kemasan berbeda yang diuji kandungan nutrisi, ketengikan dan kandungan aflatoksin.

\section{Metode Penelitian}

Persiapan sampel konsentrat sapi potong dari formulasi bahan (bungkil inti sawit, dedak padi, ubi kayu, dan mineral), setelah tercampur di kemas dengan kemasan woven bag dilapisi plastik dan woven bag tidak dilapisi plastik kemudian disimpan selama 3 bulan dan dilakukan pemanenan untuk selama penyimpanan 1, 2, dan 3 bulan.

Penyimpanan di lakukan di gudang penyimpanan. Penelitian menggunakan Rancangan Acak Lengkap (RAL) Pola Faktorial 2x3x3 (Steel dan Torrie, 1991) dengan dua faktor A, tiga faktor $\mathrm{B}$ dan tiga kali pengulangan dengan peubah yang diamati yaitu: kualitas nutrisi dengan analisis proksimat (Penurunan Bahan kering, Penurunan Lemak Kasar, Penurunan Protein Kasar) menggunakan metode AOAC, Peningkatan ketengikan diukur dengan metode analisis bilangan TBA (Thiobarbituric Acid) dan Peningkatan kandungan alfatoksin dengan metode Prinsip Direct Competitive ELISA (Enzyme Linked Immunosorbent Assay).

\section{HASIL DAN PEMBAHASAN}

\section{Pengaruh Perlakuan Terhadap Penurunan Bahan Kering Konsentrat}

Hasil analisis keragaman menunjukkan ada interaksi yang berbeda nyata antara jenis kemasan (faktor A) dan lama penyimpanan (faktor B) terhadap penurunan kandungan bahan kering konsentrat, masing-masing faktor berpengaruh sangat nyata $(\mathrm{P}<0,01)$ terhadap penurunan bahan kering konsentrat. Hasil dilakukan uji lanjut menggunakan DMRT bahwa antar perlakuan berpengaruh nyata terhadap penurunan BK konsentrat.

Rataan penurunan bahan kering semakin lama konsentrat dipenyimpanan semakin tinggi penurunan bahan kering (Tabel 1). Hal ini disebabkan terjadinya penyerapan uap air dari luar ke dalam bahan sehingga kadar air bahan naik. Hal sama juga dinyatakan oleh Ardiansyah (2012) menyatakan bahwa salah satu bahan penyusun konsentrat yaitu dedak padi mudah menyerap air karena terjadi kontak dengan udara luar, sehingga kandungan bahan kering menurun selama penyimanan.

Penurunan paling tinggi diperoleh A1B3 yaitu $4,18 \%$, paling rendah penurunan pada A2B3 yaitu $0,53 \%$. Penurunan BK ini sejalan dengan lama penyimpanan, semakin lama disimpanan semakin tinggi bahan kering, sesuai dengan lama penyimpanan, semakin lama disimpan semakin tinggi penurunan bahan kering. Hal ini disebabkan oleh terjadinya peningkatan kadar air sehingga berpengaruh terhadapa mutu konsentrat Sesuai dengan pendapat dari Herawati (2008), 
Tabel 2. Rataan kandungan penurunan protein kasar konsentrat (\%)

\begin{tabular}{lcccc}
\hline \multirow{2}{*}{ Jenis Kemasan } & \multicolumn{3}{c}{ Waktu Penyimpanan } & \multirow{2}{*}{ Rataan } \\
\cline { 2 - 4 } & $\mathrm{B} 1$ & $\mathrm{~B} 2$ & $\mathrm{~B} 3$ & \\
\hline $\mathrm{A} 1$ & $11,13^{\mathrm{cA}}$ & $21,13^{\mathrm{bA}}$ & $35,69^{\mathrm{aA}}$ & 22,65 \\
A2 & $8,43^{\mathrm{cB}}$ & $15,35^{\mathrm{bB}}$ & $25,21^{\mathrm{aB}}$ & 16,33 \\
\hline Rataan & 9,78 & 18,24 & 30,45 & \\
\hline
\end{tabular}

Keterangan: nilai-nilai dengan Superskrip huruf lebih kecil berbeda pada baris sama serta nilai dengan superskrip huruf besar yang berbeda pada kolom yang sama menunjukkan perbedaan yang sangat nyata $(\mathrm{P}<0,01)$

faktor yang sangat berpengaruh terhadap penurunan mutu produk pangan adalah perubahan kadar air dalam produk. Salah satu produk pangan yang mudah menyerap air dan terjadi kontak dengan udara luar adalah dedak padi (Ardiansyah, 2012).

Jenis kemasan menunjukkan pengaruh berbeda sangat nyata $(\mathrm{P}<0,01)$ terhadap penurunan bahan kering, penurunan BK pada perlakuan A1 kemasan woven bag 2,96\% lebih tinggi dari A2 (woven bag dilapisi plastik) yaitu $1,71 \%$. Tingginya penurunan bahan kering konsentrat pada kemasaan woven bag disebabkan karna terjadi kontaminasi dengan udara luar. Buckle et al. (2013) mengemukakan bahwa masa simpan produk lebih lama dengan menggunakan kemasan yang dapat menghambat gas dengan baik dan luas permukaan yang lebih kecil.

\section{Pengaruh Perlakuan Terhadap Penurunan Protein Kasar}

Hasil analisis keragaman menunjukkan terjadi interaksi berbeda sangat nyata $(\mathrm{P}<0,01)$ antara faktor $\mathrm{A}$ dan faktor $\mathrm{B}$ terhadap penurunan protein kasar konsentrat. Hasil uji DMRT diperoleh bahwa penurunan PK antar perlakuan berpengaruh sangat nyata. Penurunan PK tertinggi diperoleh pada perlakuan A1B3 yaitu $35,69 \%$ dan paling rendah pada perlakuan A2B1 sebesar $8,43 \%$ (Tabel 2). Faktor lama penyimpanan berpengaruh sangat nyata terhadap penurunan PK konsentrat, dimana semakin lama disimpan, maka PK akan semakin menurun. Suyitno dan Kamarijani (1996), menyatakan bahwa komponen pengendali perubahan kadar protein kasar adalah kadar air, selain itu juga disebabkan adanya degradasi protein selama penyimpanan. Ditambahkan oleh Supriyati et al. (1996) yang menyatakan bahwa semakin tinggi degradasi zat makanan semakin lama disimpan.

Jenis Kemasan berpengaruh sangat nyata $(\mathrm{P}<0,01)$ terhadap penurunan protein kasar dengan rata-rata A1 yaitu 22,65\%, dan A2 yaitu 16,33\%. Penurunan protein kasar konsentrat yang woven bag dilapisi plastik lebih rendah dari woven bag saja, karena woven bag yang dilapisi plastik miliki luas permukan yang lebih kecil sehingga pengurangi kontaminasi dengan udara luar.

\section{Pengaruh Perlakuan Terhadap Penurunan Lemak Kasar}

Hasil analisis keragaman menunjukkan adanya interaksi faktor Adan Faktor B terhadap penurunan kadar lemak kasar konsentrat. Masing-masing faktor memberikan pengaruh berbeda sangat nyata terhadap penurunan kandungan lemak kasar $(\mathrm{P}<0,01)$. Penurunan lemak kasar konsentrat tertinggi yaitu 25,42\% diperoleh pada perlakuan A1B3 dan paling rendah $4,11 \%$ yaitu pada perlakuan A2B1 (Tabel 3).

Jenis kemasan woven bag dan woven bag yang dilapisi plastik menunjukkan berbeda sangat nyata $(\mathrm{P}<0,01)$. Penurunan kadar lemak yang lebih tinggi terdapat pada woven bag yang dilapisi plastik. Hal ini disebabkan oleh kemasan yang dilapisi plastik memiliki kemampuan menghambat kontaminasi dari udara luar sehingga penurunan lemak kasarnya lebih rendah dari kemasan woven bag saja. syarief dan irawati (1988) menyatakan bahwa plastik terbuat dari 
Tabel 3. Rataan penurunan kandungan lemak kasar konsentrat (\%)

\begin{tabular}{lcccc}
\hline \multirow{2}{*}{ Jenis Kemasan } & \multicolumn{3}{c}{ Waktu Penyimpanan } & \multirow{2}{*}{ Rataan } \\
\cline { 2 - 4 } & $\mathrm{B} 1$ & $\mathrm{~B} 2$ & $\mathrm{~B} 3$ & \\
\hline $\mathrm{A} 1$ & $6,82^{\mathrm{cA}}$ & $16,44^{\mathrm{bA}}$ & $25,42^{\mathrm{aA}}$ & 16,23 \\
$\mathrm{~A} 2$ & $4,11^{\mathrm{cB}}$ & $9,22^{\mathrm{bB}}$ & $18,84^{\mathrm{aB}}$ & 10,73 \\
\hline Rataan & 5,46 & 12,83 & 22,13 & \\
\hline
\end{tabular}

Keterangan: nilai-nilai dengan Superskrip huruf lebih kecil berbeda pada baris sama serta nilai dengan superskrip huruf besar yang berbeda pada kolom yang sama menunjukkan perbedaan yang sangat nyata $(\mathrm{P}<0,01)$

polyethylene yang mempunyai kemampuan terhadap permeabilitas uap air.

Lama penyimpanan pada 1 bulan, 2 bulan, dan 3 bulan berpengaruh sangat nyata terhadap penurunan lemak kasar. Adapun penurunan masing-masing LK adalah $5,46 \%$ pada B1 yaitu $12,83 \%$ selama dua bulan dan B3 yaitu 22,13\%. Semakin lama penyimpanan semakin tinggi penurunan lemak kasar. Sesuai pendapat Winarno (2008) oksidasi merupakan reaksi berantai pembentukan radikal yang melepaskan hidrogen. Reaksi tersebut menyebabkan kerusakan lemak, hal ini disebabkan oleh otooksidasi radikal asam lemak tidak jenuh. Semakin lama penyimpanan konsentrat semakin tinggi juga penurunan kadar lemak konsentrat yang disebabkan oleh terjadinya oksidasi. Ditambahkan oleh Syamsu (2000) yang menyatakan bahwa lama penyimpanan akan meningkatkan oksidasi lemak yang ditunjukan dengan bertambahnya bilangan peroksida. Jenis kemasan menunjukkan pengaruh berbeda sangat nyata $(\mathrm{P}<0,01)$ terhadap lemak kasar, setelah di uji DMRT diperoleh bahwa penurunan kadar lemak kasar pada perlakuan A1 kemasan woven bag $16,23 \%$ dan A2 (woven bag dilapisi plastik) yaitu 10,73\% (Tabel 3).

Pada kemasan woven bag menunjukkan penurunan lemak kasar lebih tinggi dari kemasan woven bag dilapisi plastik. Hal ini di sebabkan karena kemasan woven bag penurunan lemak kasar lebih tinggi karena dapat menghambat kontaminasi dari luar, sesuai dengan pendapat Syarief et al. (1989), bahan kemasan mempunyai kemampuan dalam menahan kontaminasi dengan udara luar, hal ini ditentukan oleh ada tidaknya lubang-lubang yang sangat kecil pada permukaannya. Triyanto et al. (2013) menyatakan bahwa faktor-faktor yang berperan dalam mempercepat kerusakan lemak adalah kandungan minyak ataupun kontak dengan udara luar dan kadar air bahan.

Lemak kasar konsentrat pada penelitian ini masih dalam taraf standar, hal ini didasari pada ketetapan standar pakan ternak oleh standarisasi nasional yang menyatakan bahwa kandungan lemak kasar maksimumyaitu $6 \%$.

\section{Pengaruh Perlakuan Terhadap Peningkatan Ketengikan Konsentrat}

Hasil penelitian menunjukkan bahwa terjadi interaksi berbeda sangat nyata $(\mathrm{P}<0,01)$ faktor A dengan faktor $\mathrm{B}$ terhadap tingkat ketengikan konsentrat. Masing-masing faktor berpengaruh sangat nyata $(\mathrm{P}<0,01)$ terhadap tingkat ketengikan konsentrat. Hasil uji DMRT menunjukkan bahwa antar perlakuan berpengaruh sangat nyata. Tingkat Ketengikkan tertinggi diperoleh pada A1B3 yaitu $57,75 \%$ dan yang terendah pada perlakuan A2B1 yaitu 12,99\%. Faktor lama penyimpanan berbeda sangat nyata $(\mathrm{P}<0,01)$ terhadap tingkat ketengikkan konsentrat, semakin lama penyimpanan semakin tinggi tingkat ketengikkan konsentrat, pada 1 bulan yaitu $16,66 \%$, 2 bulan $26,44 \%$ dan 3 bulan 43,91\% (Tabel 4). Ketengikan disebabkan terjadinya okdasi selama penyimpanan, kerusakan lemak konsentrat yang disimpan sehingga menyebabkan reaksi oksidasi (kontak dengan udara) dan menimbulkan bau tengik selama penyimpanan. 
Tabel 4. Rataan Peningkatan ketengikan (mg MDA/Kg) konsentrat (\%)

\begin{tabular}{lcccc}
\hline \multirow{2}{*}{ Jenis Kemasan } & \multicolumn{3}{c}{ Lama Penyimpanan } & \multirow{2}{*}{ Rataan } \\
\cline { 2 - 4 } & $\mathrm{B} 1$ & $\mathrm{~B} 2$ & $\mathrm{~B} 3$ & $39,75^{\mathrm{aA}}$ \\
\hline $\mathrm{A} 1$ & $26,34^{\mathrm{cA}}$ & $34,70^{\mathrm{bA}}$ & $390,07^{\mathrm{aB}}$ & 20,41 \\
\hline A2 & $12,99^{\mathrm{cB}}$ & $18,18^{\mathrm{bB}}$ & 30,01 \\
\hline Rata-rata & 19,66 & 26,44 & 43,91 & \\
\hline
\end{tabular}

Keterangan: nilai-nilai dengan Superskrip huruf lebih kecil berbeda pada baris sama serta nilai dengan superskrip huruf besar yang berbeda pada kolom yang sama menunjukkan perbedaan yang sangat nyata $(\mathrm{P}<0,01)$

Semakin lama penyimpanan semakin tinggi terhadap peningkatan ketengikan konsentrat, sedangkan semakin tinggi penurunan bahan kering serta penurunan lemak kasar oleh karena terjadi oksidasi. Syamsu (2000) yang menyatakan bahwa lama penyimpanan akan meningkatkan oksidasi lemak yang ditunjukan dengan bertambahnya bilangan peroksida. Hal ini ditambahkan oleh ASA (2000) menyatakan bahwa semakin tinggi angka peroksidanya maka semakin tinggi pula tingkat ketengikannya. Oksigen dapat mempercepat kerusakan lemak, yaitu dengan terjadinya ketengikan secara oksidatif pada bahan pangan yang berlemak contohnya kacang. Proses oksidasi dapat dikendalikan dengan menurunkan konsentrasi oksigen dalam kemasan (Leufven et al., 2007).

Jenis kemasan menunjukkan pengaruh berbeda sangat nyata $(\mathrm{P}<0,01)$ terhadap peningkatkan ketengikan konsentrat. Jenis kemasan woven bag yang dilapisi plastik menunjukkan tingkat ketengikan lebih rendah daripada kemasan woven bag saja, pada A1 diperoleh 39,60\% sedangkan A2 diperoleh $20,41 \%$. Kemasan woven bag yang dilapisi plastik mampu menghambat kontaminasi dari udara luar, ditambahkan oleh Syarief et al. (1989) bahan kemasan mempunyai kemampuan dalam menahan kontaminasi dengan udara luar, hal ini ditentukan oleh ada tidaknya lubang-lubang yang sangat kecil pada permukaannya.

Oksidasi lipid tidak hanya menghasilkan rasa tengik, tapi juga menurunkan nilai gizi makanan dengan formasi produk oksidasi, Terjadi oksidasi disebabkan oleh autooksidasi radikal asam lemak tidak jenuh dalam lemak. Autooksidasi dimulai dengan pembentukan radikal-radikal bebas yang disebabkan oleh factor- faktor yang mempercepat reaksi seperti cahaya, panas, peroksida (Winarno, 2004). Tingkat ketengikan konsentrat pada bulan ketiga dengan kemasan woven bag yang dilapisi plastic melebihi batas maksimal yaitu 3,23mg $\mathrm{MDA} / \mathrm{Kg}$ dengan peningkatan $30,07 \%$, yang ditetapkan Badan Standarisasi Nasional (1991) yaitu 3,0mg malonaldehid/ Kg sampel.

\section{Pengaruh Perlakuan Terhadap Peningkatan Kandungan Aflatoksin}

Hasil analisis statistik menunjukkan ada interaksi berbeda sangat nyata antara faktor A (jenis kemasan) dengan faktor B (lama penyimpanan) terhadap kandungan aflatoksin konsentrat. Masing-masing faktor menunjukkan pengaruh yang berbeda sangat nyata $(\mathrm{P}<0,01)$ terhadap peningkatan kandungan aflatoksin Setelah dilakukan uji DMRT diperoleh bahwa peningkatan kandungan aflatoksin paling tinggi diperoleh pada perlakuan A1B3 yaitu 48,26\%, paling rendah pada A2B1 yaitu 2,65\% (Tabel 5).

Kandungan aflatoksin konsentrat dipengaruhi oleh lama penyimpanan dan jenis kemasan. Semakin lama disimpan semakin tinggi kandungan aflatoksinnya, hal ini di sebabkan karena peningkatan kadar air konsentrat. Trisyulianti et al. (2003) menyatakan bahwa wafer yang terserang jamur lebih cepat adalah wafer yang memiliki kadar air tinggi. Aktivitas mikroorganisme dapat ditekan pada kadar air 12\%-14\%, sehingga bahan pakan tidak mudah berjamur 
Tabel 5. Rataan peningkatan kandungan aflatoksin (ppb) konsentrat selama penyimpanan

\begin{tabular}{lcccc}
\hline \multirow{2}{*}{ Jenis Kemasan } & \multicolumn{3}{c}{ Lama penyimpanan } & \multirow{2}{*}{ Rataan } \\
\cline { 2 - 4 } & $\mathrm{B} 1$ & $\mathrm{~B} 2$ & $\mathrm{~B} 3$ & \\
\hline $\mathrm{A} 1$ & $11,33^{\mathrm{cA}}$ & $31,92^{\mathrm{bA}}$ & $48,26^{\mathrm{aA}}$ & 30,50 \\
A2 & $2,65^{\mathrm{cB}}$ & $12,93^{\mathrm{bB}}$ & $18,69^{\mathrm{aB}}$ & 11,42 \\
\hline Rata-rata & 6,99 & 22,42 & 33,47 & \\
\hline
\end{tabular}

Keterangan: nilai-nilai dengan Superskrip huruf lebih kecil berbeda pada baris sama serta nilai dengan superskrip huruf besar yang berbeda pada kolom yang sama menunjukkan perbedaan yang sangat nyata $(\mathrm{P}<0,01)$

dan membusuk. Hasil penelitian ini peningkatan kandungan aflatoksin tertinggi yaitu $48,26 \%(11,76 \mathrm{pbb})$ dimana nilai ini jauh dibawah Standar Nasional Indonesia, minimal kandungan Aflatoksin yaitu 200 ppb (Suparto, 2004). Dengan demikian konsentrat ini masih jauh dari batas maximum kandungan aflatoksin untuk konsentrat sapi potong.

\section{KESIMPULAN}

Kemasan woven bag yang dilapisi plastik lebih baik dari woven bag tanpa dilapisi plastik berdasarkan penurunan kandungan nutrisi, peningkatan ketengikan, dan peningkatkan kandungan aflatoksin yang lebih baik dengan penyimpanan selama 2 bulan.

\section{DAFTAR PUSTAKA}

Ardiansyah, M. 2012. Kajian Masa Simpan dan Kualitas Dedak Sebagai Bagian dalam Prosedur Penanganan Bahan Baku Pakan. Balai Besar Pengembangan Teknologi Tepat Guna. LIPI Subang.

ASA. 2000. Feed Quality Management Workshop. Penentuan Bilangan Peroksida. Ciawi.

Badan Standarisasi Nasional. 1991. SNI 01-2352-1991. Pengujian angka asam thiobarbiturat. Jakarta: Badan Standarisasi Nasional.

Buckle, K. A., R. A. Edwards., G. H. Fleet, and M. Wooton. 2013. Ilmu Pangan. UI Press, Jakarta.
Herawati, H. 2008. Penentuan umur simpan pada produk pangan. Prosiding Jurnal Litbang Pertanian. Hlm. 124-130.

Leufven, A., Sedaghat, N. and Habibi, M. B. 2007. Infl uence of different packaging systems on stability of raw dried pistachio nuts at various conditions. SID 27-36.

Retnani, Y. 2015. Proses Industri Pakan. Bogor. IPB Press kampus IPB Taman Kencana.

Steel, R. G. D. dan J. H. Torrie. 1991. Prinsip dan Prosedur Statistika. Diterjemahkan oleh Bambang Sumantri. PT. Gramedia Pustaka Utama. Jakarta

Suparto, D. I . A. H. 2004. Situasi cemaran mikotoksin pada pakan di Indonesia dan perundang-undangannya.Seminar Parasitologi dan Toksikologi Veteriner. Kerjasama Balai Penelitian Veteriner, Pusat Penelitian dan Pengembangan Peternakan dengan Department for Development (DOD-UK), Bogor 20-21 April, 2004. hlm. 131-142.

Supriyati., T. Haryati., T. Purwadaria, dan I. P. Kompiang. 1996. Pengaruh jenis kemasan, suhu ruang dan lama penyimpanan limbah sagu terfermentasi terhadap kualitas nutrisi. Pros. Temu Ilmiah Hasil-hasil Penelitian Peternakan. Bogor, 9 - 11 Januari 1996.

Suyitno dan Kamarijani. 1996. Dasar-dasar Pengemasan. Rineka Cipta. Jakarta.

Syamsu, J. A. 2000. Pengaruh waktu penyimpanan dan jenis kemasan terhadap kualitas dedak padi. Bul. 
Nutrisi dan Makanan Ternak, Vol.1 (2): 75-84.

Syarief. R., S. Santausa, dan Isyana. 1989. Teknologi Pengemasan Pangan, PAU Pangan dan Gizi, IPB Bogor.

Syarief, R. dan A. Irawati. 1988. Pengetahuan Bahan untuk Industri Pertanian.Media Sarana Perkasa, Jakarta.

Trisyulianti, E., Suryahadi, dan V. N. Rakhma. 2003. Pengaruh penggunaan molases dan tepung gaplek sebagai bahan perekat terhadap sifat fisik wafer ransum komplit. Institut Pertanian Bogor. Media Peternakan. 26(2):35-40.
Triyanto, E., B. W. H. E Prasetiyono, dan S. Mukodiningsi. 2013. Pengaruh Bahan Pengemas dan Lama Simpan Terhadap Kualitas Fisik dan Kimia Wafer Pakan Komplit Berbasis Limbah Egroindustri. J. Anim. Agr. 2. (1): 400- 409.

Utomo, R. 2003. Penyediaan Pakan di Daerah Tropik. Pidato Pengukuhan Guru Besar pada Fakultas Peternakan, Universitas Gadjah Mada, Yogyakarta.

Winarno F. G. 2008. Kimia Pangan dan Gizi. Jakarta: Gramedia Pustaka Utama.

Zuhra, C. F. 2006. Flavor (Citarasa). Departemen FMIPA. Universitas Sumatera Utara, Medan. 